\title{
CONSIDERATIONS CONCERNING THE STREAM OF HEAT TRANSFERRED FROM ROCK MASS INTO MINE VENTILATION AIR AND THE UTILIZATION OF THIS HEAT BY MEANS OF AIR COOLING INSTALLATIONS
}

\section{ÚVAHA TÝKAJÍcí SE PŘESTUPU TEPLA Z HORNINOVÉHO MASÍVU DO DŮLNÍHO OVZDUŠí A POUŽITÍ CHLADICÍCH ZAŘíZENÍ K VYUŽITÍ TOHOTO TEPLA}

\author{
Józef KNECHTEL \\ D.Sc., Head of laboratory of mine ventilation and mine air-conditioning, Central Mining \\ Institute, 40-166 Katowice, Plac Gwarków 1, Poland, tel.: +48 322592194 \\ e-mail:JKnechtel@gig.katowice.pl, j.knechtel@gig.eu
}

\begin{abstract}
This paper deals with the feasibility of utilization of the heat carried away with the air stream ventilating a mine after closing down mining operations. The problem is that, although the temperature of air flowing underground is rather high (above $35^{\circ} \mathrm{C}$ ), the air temperature at the surface level drops to about $25^{\circ} \mathrm{C}$. For that reason it was proposed to cool down the hot air underground and to transport the hot water from cooling machines to the surface level. However, such a solution is not realistic in closed-down mines. So, another idea was considered consisting in exploiting the thermal energy of the exhaust air stream in functioning mines. Further the cooling potential of Polish mines was surveyed. It emerged that for the mines with an active cooling potential in the range of a couple of MW it can be economically viable to transfer the gained thermal energy released due to surface condensation and to use that energy for communal heating.
\end{abstract}

\section{Abstrakt}

Článek se zabývá možnostmi využití tepla, které je odváděno důlním ovzduším na povrch po ukončení dobývání. I když teplota tohoto ovzduší v dole je poměrně vysoká (více jak $35^{\circ} \mathrm{C}$ ), tak po výstupu na povrch se tato teplota snižuje na cca $25^{\circ} \mathrm{C}$. Proto bylo navrženo, aby teplé ovzduší bylo schlazováno v dole a na povrch by se odváděla teplá voda pocházející z chladících zařízení. Toto řešení je ale málo reálné v př́ípadě dolu, kde již byla těžba ukončena. Proto další návrh se týká využití tepla obsaženého v použitém důlním ovzduší činných dolů. Byl vyhodnocen chladící potenciál polských kamenouhelných dolů. $Z$ této analýzy vyplývá, že $\mathrm{v}$ dolech $\mathrm{s}$ činným chladícím potenciálem řádově několika $\mathrm{MW}$, může být ekonomicky výhodný záměr spojený s odváděním kondenzačního tepla, pocházejícího z chladících zařízení, na povrch a jeho využití pro vytápění. 
Key words: Air-conditioning, main fan, natural draught, longwall gate.

\section{INTRODUCTION}

This paper [4] investigates the feasibility of utilization of the geothermal heat transferred within the mine air stream to the ambient atmosphere on the surface; the considerations are restricted to the period after closing down mining operations in the mine. It was assumed that when the main fans are shut down the air movement across the mine is being induced by natural draught only. From the work by Bystron [1], among others, it is known that the natural draught energy is a season-dependent phenomenon. In the summer period, when the temperature of ambient air at the surface level is $17^{\circ} \mathrm{C}$, the energy of natural draught is $e_{n v}=87 \mathrm{~J} / \mathrm{m}^{3}$, whereas in the spring and autumn seasons $e_{n v}=349 \mathrm{~J} / \mathrm{m}^{3}$. The airflow volumes induced by natural draught in the summer-autumn period would be about $36 \%$ of the volume induced by the mine fans during normal operations, whereas in the summer period this value would be $20 \%$. Through the use of the prognostic method described in the paper [3], a number of variant prognoses of climatic conditions were prepared for the exploitation panel of high virgin rock temperature. The maximum value of the temperature of air underground was estimated at $38,8{ }^{\circ} \mathrm{C}$ directly after closing down the mining operations, and at $35,2^{\circ} \mathrm{C}$ after 10 years of the ventilation of underground workings. However, the calculated temperature of air at the surface level was much lower and amounted to about $25^{\circ} \mathrm{C}$, much too low for commercial use.

This paper studies the feasibility of solutions consisting in cooling down the air stream underground and subsequent transport of the thermal energy, stored in the hot water from cooling devices, to the surface. In order to assess the amount of energy that can be released from the hot rock mass, the influence of lengthy air flow through an airway on the rock mass cooling was studied. In the next step, the amount of the heat stream transferred from the rock mass into the air stream was estimated, and finally the feasibility of utilization of the thermal energy from the hot rock mass surrounding mine workings was considered.

\section{THE INFLUENCE OF NATURAL DRAUGHT INDUCED BY THE VENTILATION ON ROCK MASS COOLING}

We decided to estimate the influence of natural draught induced by the ventilation on rock mass cooling by means of numerical calculations relating to the rock mass surrounding a virtual exploitation panel consisting of a longwall and longwall gates. It follows from the work [4] that the intensity of the heat stream flowing away from the rock mass to the air stream decreases with time.

During the coal extraction phase the distribution of air temperature is influenced by the heat inflow from the rock mass and from so called technological sources such as engines driving hauling devices, pumps, shearers as well as from transformers, cables and from coal oxidation, hot coal transported by a hauling system. After the termination of mining operations and shutting down the fans the heat from the rock mass and from coal oxidations remains the only source of heat. The temperature of air flowing along the working is related only to the outer temperature of ribs. The outer temperature of ribs is related to the cool-down rate of rock mass. Through the use of the method described in the paper [2], within the rock mass, surrounding the longwall and the longwall gates, several zones of different cool-down patterns of rock mass due to natural draught induced by the ventilation were 
determined. The calculations were carried out for the period just before the termination of mining operations and for the following periods afterwards: 2 weeks, 1 month, 3 months, 1 year, 2 years, 5 years, 10 years and 20 years.

The results of the calculations were presented in the paper [8]. The findings indicate that the distribution of temperature of the outer surface of ribs changes not only in time, but also across the length of the working. For the upper longwall gate (after the termination of mining operations), the difference between the outer temperature of ribs at the intake and one at the exhaust of the gate is about $6 \div 7^{\circ} \mathrm{C}$. In the case of the longwall itself this difference is about $2^{\circ} \mathrm{C}$, whereas the difference of temperatures along the upper longwall gate is about $5^{\circ} \mathrm{C}$. This has an impact on the temperature distribution within the rock mass. The study [8] indicates that the cooled-down zone (where the actual temperature of rock mass is lower than the virgin rock temperature) is larger at the intake of the working then at its exhaust end. For the lower gate (during the exploitation period and for short time after the termination of exploitation) the length of the cooled-down zone is up to 21 meters. As time progresses, this zone becomes larger - after a year its length is $27 \mathrm{~m}$, after 2 years $31 \mathrm{~m}$, after 5 years $42 \mathrm{~m}$, after 10 years $58 \mathrm{~m}$ and after 20 years $93 \mathrm{~m}$. For the upper gate the length of the cooled-down zone is changing roughly in the same manner, but there is a difference caused by the fact that much warmer air is flowing along the upper gate than along the lower gate and the longwall itself. The heat stream flowing from the rock mass and the oxidation heat cause further temperature increase. And it is chiefly the oxidation heat that causes the temperature of outer ribs of the upper gate to increase above the virgin rock temperature. The zone of the temperature higher than the virgin rock temperature advances deep into the rock mass. The presence of the temperature above the virgin rock temperature behind the outer surface of ribs was observed yet by Muzyczuk [9].

Based on the findings from [8], figures 1, 2 and 3 were drawn. The graphs illustrate the isotherms of the rock mass temperature around the lower gate, $800 \mathrm{~m}$ in length (Fig. 1), the longwall, $200 \mathrm{~m}$ in length (Fig, 2) and the upper gate, $1200 \mathrm{~m}$ in length (Fig. 3). The graphs show the temperature distribution for the period just before the termination of mining operations. 


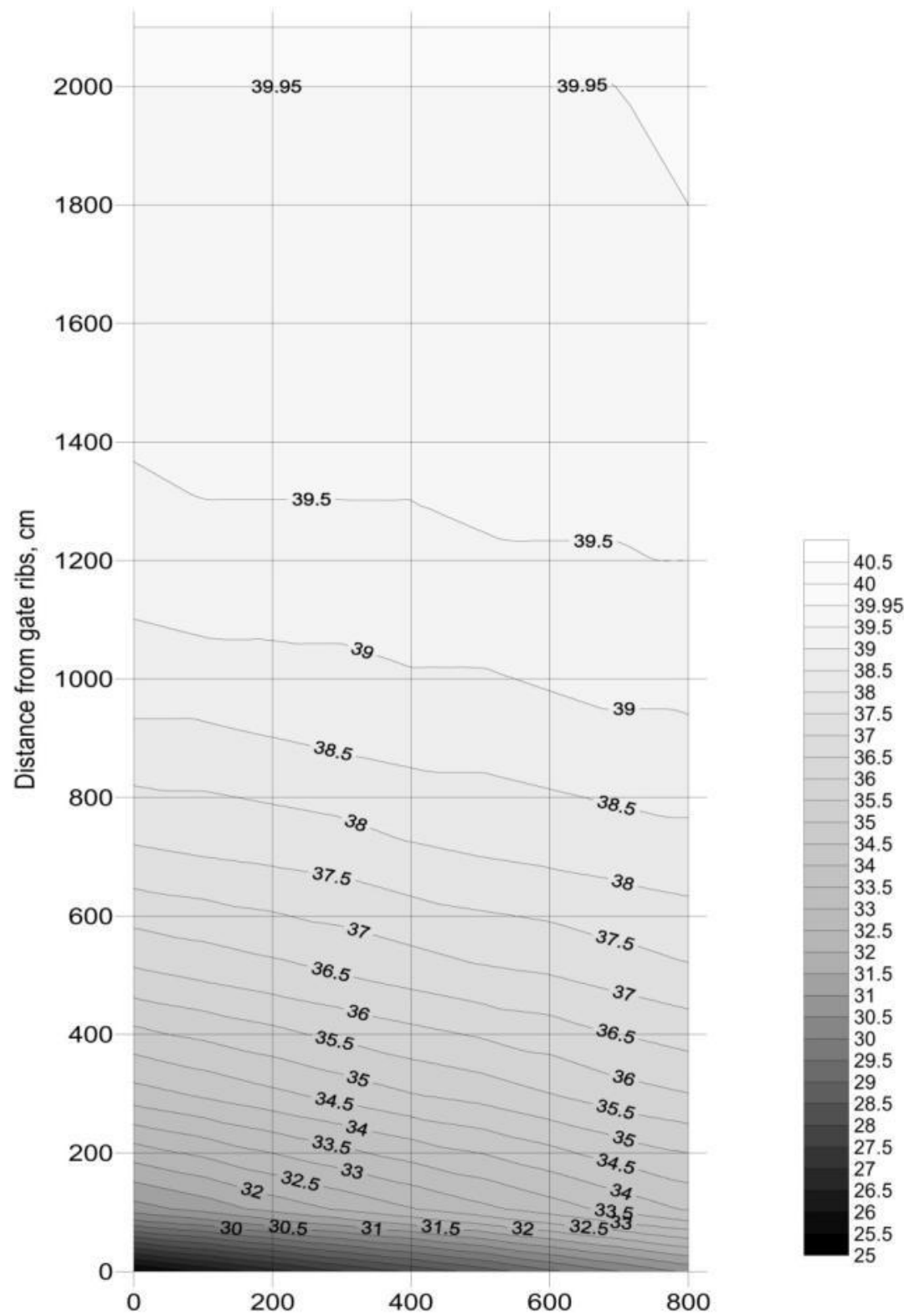

Fig. 1 Cooling down the rock mass around the lower longwall gate directly before the termination of mining activities 


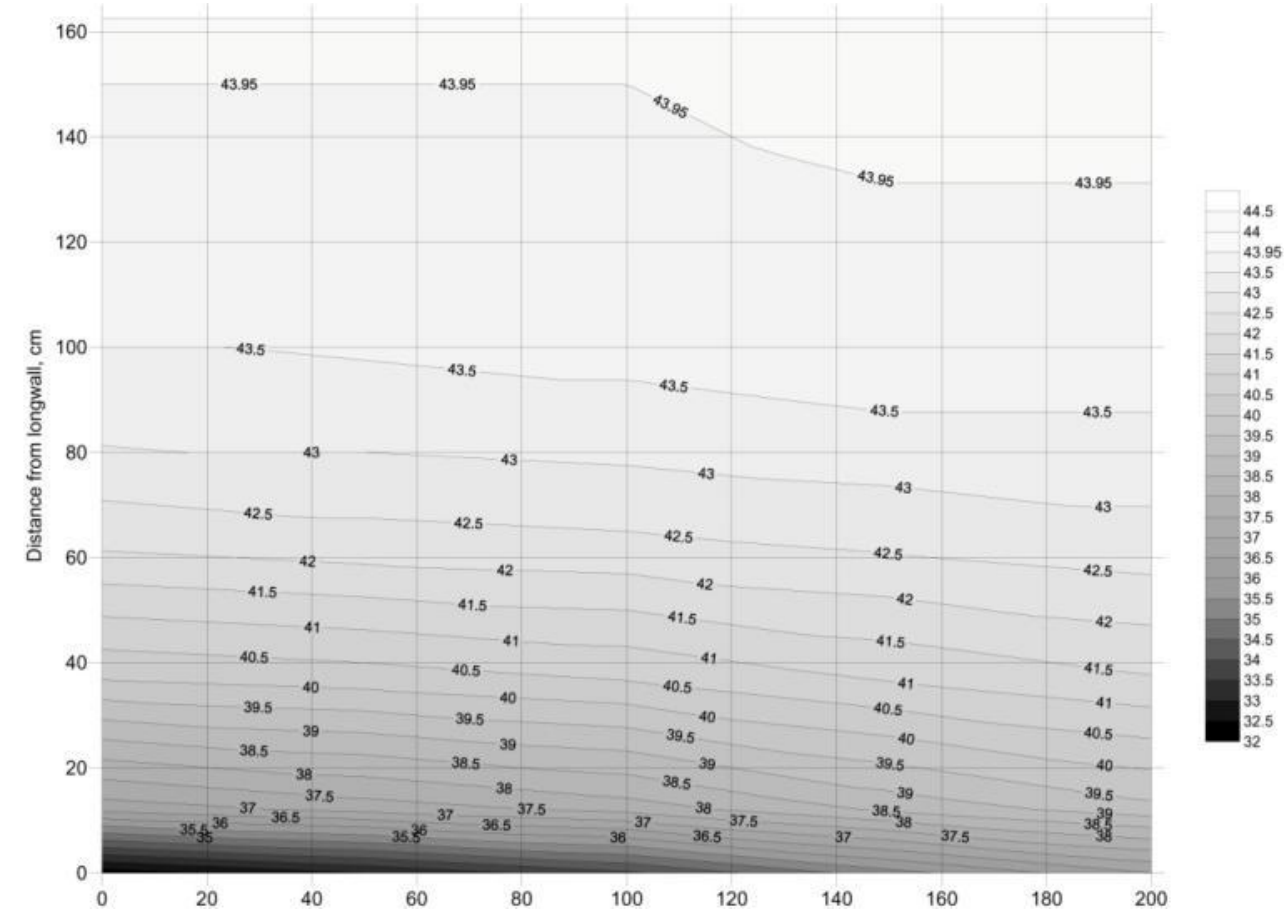

Fig. 2 Cooling down the rock mass around the longwall directly before the termination of mining activities

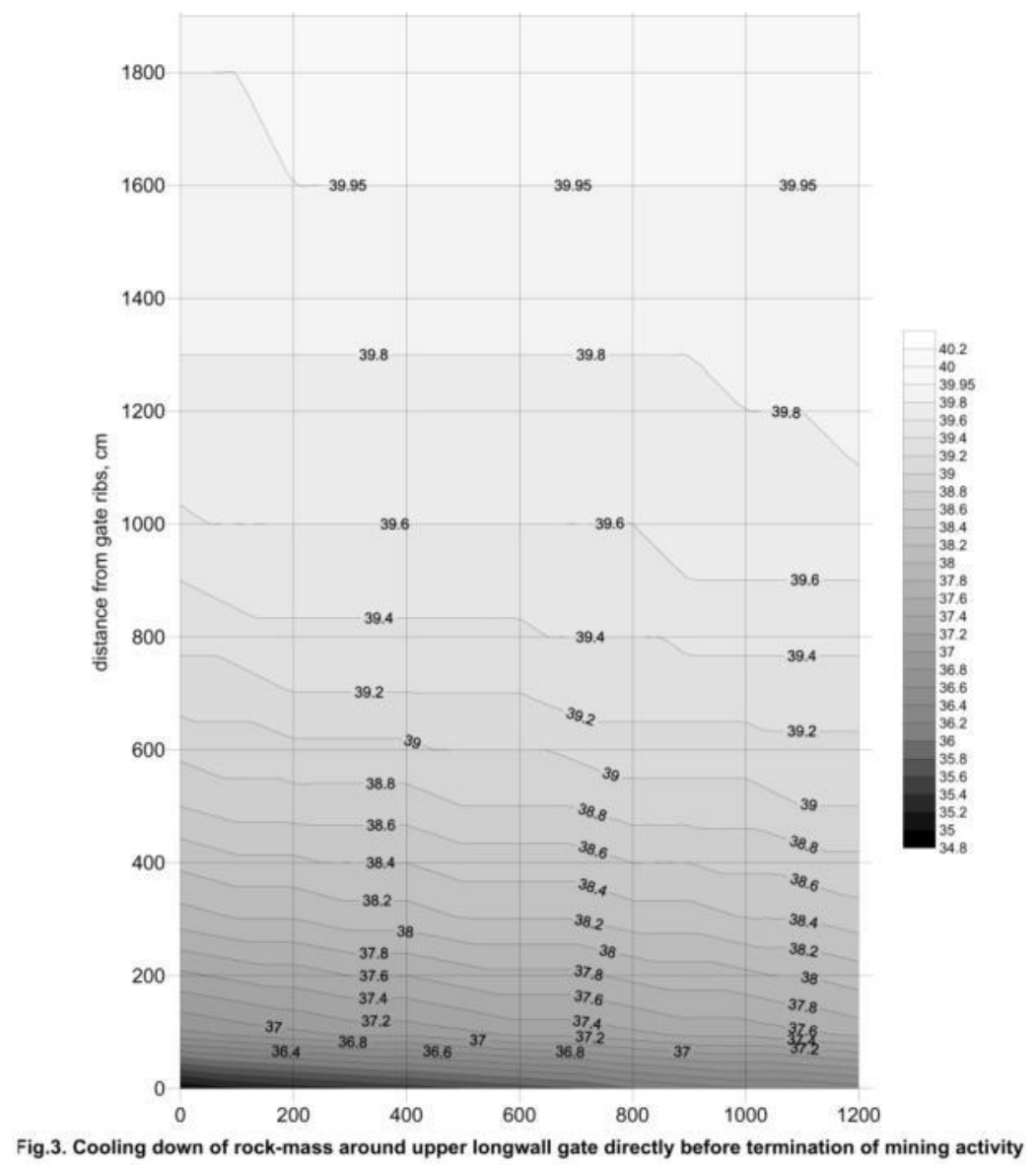

Fig. 3 Cooling down the rock mass around the upper longwall gate directly before the termination of mining activities 
It can be easily seen that the isotherms are not horizontal lines and their slope increases in the vicinity of ribs of the working. Further deep into the rock mass the lines become straighter, almost horizontal. The analogous graphs (Fig. 4, 5 and 6) illustrate the isotherms distribution after the period of 10 years after the termination of mining operations. Comparing the graphs for the respective workings, it is evident that as time progresses the cooled-down zone advances deep into the rock mass.

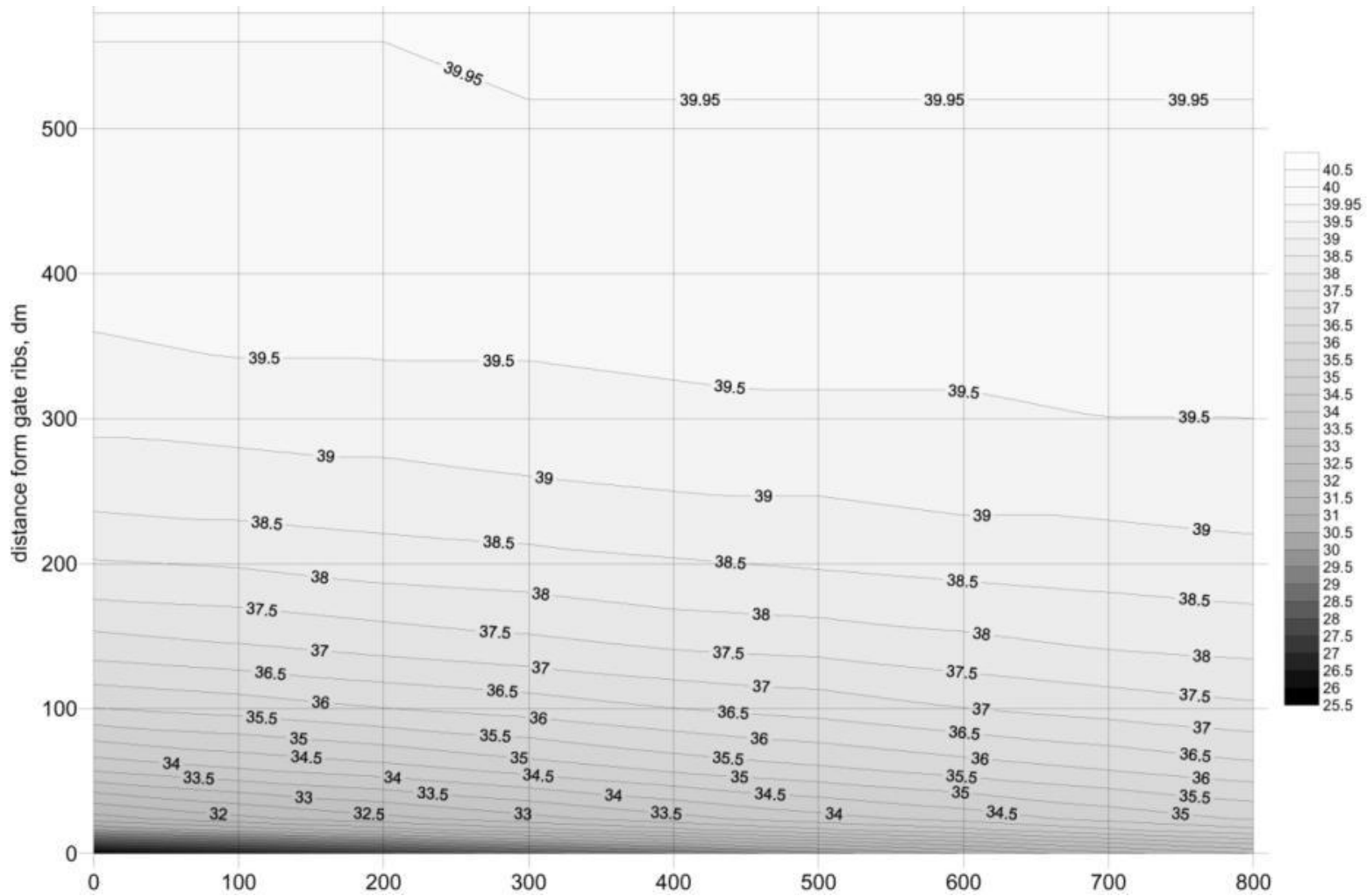

Fig. 4 Cooling down the rock mass around the longwall gate - 10 years after the termination of mining activities 


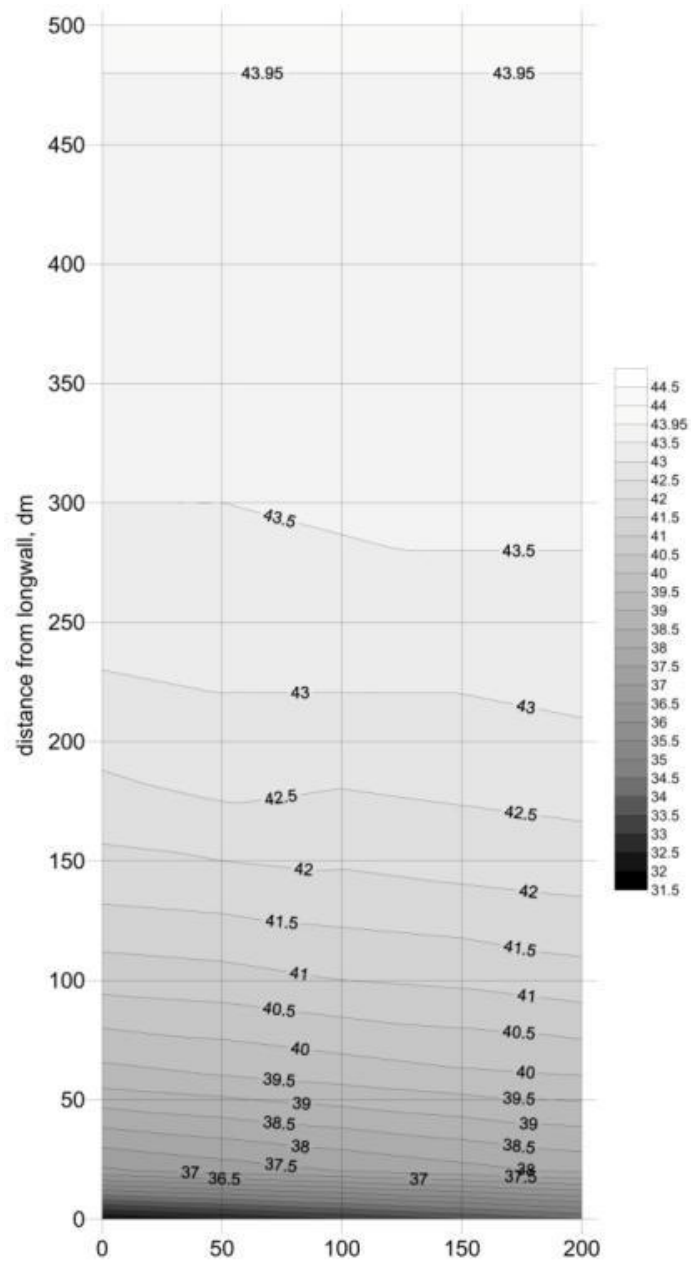

Fig. 5 Cooling down the rock mass around the longwall - 10 years after the termination of mining activities

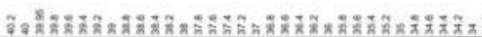

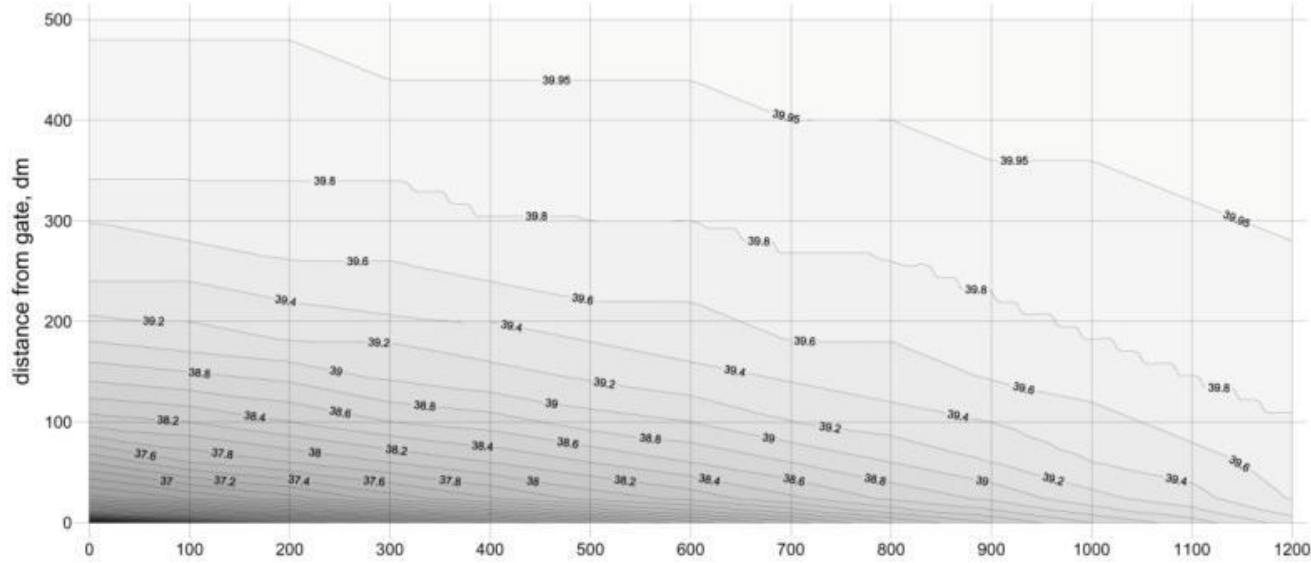

Fig. 6 Cooling down the rock mass around the upper longwall gate - 10 years after the termination of mining activities 


\section{THE HEAT STREAM FLOWING FROM THE ROCK MASS INTO THE AIR STREAM FLOWING ACROSS THE MINING PANEL}

In order to determinate the heat stream, the results of calculations discussed in section 2 were taken into consideration. Since the temperature of air as well as the temperature of rocks is changing with the length of the working, each working was divided into several sections, $50 \mathrm{~m}$ in length each. It was assumed that each of the section is surrounded by coaxial cylinders, $50 \mathrm{~m}$ in height, whose radii's ends have an equal temperature. In the next step of work, the quantities of the heat released by the regions contained within the cylindrical surfaces were determined, assuming that the average density of the rock mass in the vicinity of the longwall gates was $2000 \mathrm{~kg} / \mathrm{m}^{3}$, whereas in the vicinity of the longwall itself it was $1900 \mathrm{~kg} / \mathrm{m}^{3}$. The specific thermal capacity near the gates was assumed to be $920 \mathrm{~J} /(\mathrm{kg} \cdot \mathrm{K})$ and near the longwall it was $985 \mathrm{~J} /(\mathrm{kg} \cdot \mathrm{K})$. Multiplying the mass of a cylinder (without the coaxial cylinder of smaller radius) by the specific heat and the difference between the virgin rock temperature and the temperature after a given period of time, the heat value was obtained that was transferred across the given section of the working. The sum of the heat values for every section represented the quantity of the heat released by the rock mass after a given period of time.

Rough estimations show that during a 10-year period since the termination of mining operations the rock mass around the upper gate released 1061 GJ of heat, whereas for the rock mass around the longwall it was 2344 GJ, and in the case of the upper gate it was 10862 GJ - 23819 GJ in total. During a five-year period after the termination of coal extraction the respective values were - in the vicinity of the lower gate - 5749 GJ, the longwall 1272 GJ and the upper gate 5174 GJ, 12195 GJ in total. Multiplying these values by the average cost of the energy equal to 46 zł per GJ $(\approx 11,5 € / \mathrm{GJ})$ we obtain the potential market value of the thermal energy released from the rock mass of $1095700 \mathrm{zl}$ (273 $900 €)$ for the 10-year period and of about $561000 \mathrm{zl}(140250 €)$ for the 5-year period after the termination of mining activities in the mining section. Other simple calculations showed that the heat released by the rock mass was almost entirely transferred into the air stream flowing along the workings. The findings from the work [4] were used during the calculations of the heat amount absorbed by the air; the calculated values are as follows:

\begin{tabular}{|c|c|c|}
\hline after & 1 day & 7,5 GJ \\
\hline after & 1 week & 50,6 GJ \\
\hline after & 2 weeks & 100,2 GJ \\
\hline after & 1 month & 197,8 GJ \\
\hline after & 3 months & 611,7 GJ \\
\hline after & 1 year & 2376,0 GJ \\
\hline after & 2 years & 4638,0 GJ \\
\hline after & 5 years & 11037,0 GJ \\
\hline after & 10 years & 21136,5 GJ \\
\hline after & 20 years & 40105,3 GJ \\
\hline
\end{tabular}


The calculations were carried out for one mining region only. The average number of exploitation panels in a mine is currently 2 or 3 , each lasting about 1,5 year, therefore the results relating to the five-year period ought to be multiplied by the factor of 8 , thus making the value of the available thermal energy at about $4 \mathrm{mln} \mathrm{zł}(1 \mathrm{mln} €)$.

\section{THE REMARKS CONCERNING THE FEASIBILITY OF UTILIZATION OF THE THERMAL ENERGY CONTAINED IN THE EXHAUST AIR STREAM IN ACTIVE MINES}

As mentioned above, the quantity of the heat taken away from the rock mass and the heat released by the underground machinery is huge, but the temperature of the mine air that initially absorbed the heat underground is rather low for instance at the surface level (at the diffuser of the fan station). The better solution seems to be to transport the heat stored in the hot water from cooling devices. Usually the temperature of water, cooling a condenser, is $42 \div 43^{\circ} \mathrm{C}[10,11]$. In the case of closed down mines, in order to recapture the geothermal heat, the cooling devices ought to be kept running underground, which would not be easy from the technical and logistical points of view.

It seems that another idea, being worthy of consideration, is the utilization of the heat from air cooling installations in active mines by modifying the way by which the heat of condensation is disposed of. Instead of carrying it away along with the ventilating air (as it is the case in almost all Polish mines using air conditioning) or dissipating it in cooling towers on the surface [12], the hot water can be transported to the surface level for example by means of a three-chamber pipe feeder [11] made by SIEMAG, and then pumped into heating installations and communal facilities.

According to the annual report about the state of main natural and technical hazards in the coal industry [7] in 2009 the 23 Polish coal mines had at their disposal air cooling devices of total power equal to $59855 \mathrm{~kW}$ (Table 1).

The combined cooling power in fourteen mines, having the cooling installations of the total power output above 2 MW each, was about 49,7 MW. It is the equivalent of the thermal energy of 21464 GJ produced during one week, or $89440 \mathrm{GJ}$ in one month and $1073280 \mathrm{GJ}$ in one year. Because the median cost of $1 \mathrm{GJ}$ of the thermal energy for heating is about $46 \mathrm{zł}(11,5 €)$, it follows that during a year the cooling devices operating in Polish mines could generate the thermal energy worth 49,3 $\mathrm{mln}$ zł (12,3 $\mathrm{mln} €)$. Accordingly, in one year the mines having air cooling installations of the total power below 2MW each could produce the thermal energy worth about 6,2 mln $\mathrm{zl}$ (Table 1). 
Table 1. The quantity of the thermal energy generated by the cooling devices operating in 2009 in the Polish coal industry

\begin{tabular}{|c|c|c|c|c|c|c|c|c|c|}
\hline & \multirow[b]{2}{*}{ Category of mine } & \multirow[b]{2}{*}{$\begin{array}{l}\text { Number of } \\
\text { mines }\end{array}$} & \multirow{2}{*}{$\begin{array}{c}\begin{array}{c}\text { Cooling } \\
\text { power }\end{array} \\
\mathrm{Q}_{0}, \mathrm{~kW}\end{array}$} & \multicolumn{2}{|c|}{1 week } & \multicolumn{2}{|c|}{1 month } & \multicolumn{2}{|c|}{1 year } \\
\hline & & & & $\begin{array}{l}\text { energy, } \\
\text { GJ }\end{array}$ & $\begin{array}{c}\text { value, } \\
€\end{array}$ & $\begin{array}{c}\text { energy, } \\
\text { GJ }\end{array}$ & $\begin{array}{c}\text { value, } \\
€\end{array}$ & $\begin{array}{c}\text { energy, } \\
\text { GJ }\end{array}$ & $\begin{array}{c}\text { value, } \\
€\end{array}$ \\
\hline 1 & $\begin{array}{c}\text { Combined cooling } \\
\text { power greater than } \\
2 \mathrm{MW}\end{array}$ & 14 & 49685 & 21463,92 & 246835 & 89440,15 & 1028562 & 1073282 & 12342743 \\
\hline 2 & $\begin{array}{c}\text { Combined cooling } \\
\text { power from } 1 \text { to } 2 \\
\text { MW }\end{array}$ & 4 & 6230 & 2691,36 & 30951 & 11214,90 & 128971 & 134579 & 1547659 \\
\hline 3 & $\begin{array}{c}\text { Combined cooling } \\
\text { power from } 0,5 \text { to } \\
1 \mathrm{MW}\end{array}$ & 4 & 3640 & 1572,48 & 18084 & 6552,52 & 75354 & 78630 & 904245 \\
\hline 4 & $\begin{array}{c}\text { Combined cooling } \\
\text { power below } 0,5 \\
\text { MW }\end{array}$ & 1 & 300 & 129,60 & 1490 & 540,04 & 6210 & 6481 & 74532 \\
\hline & Total & 23 & 59855 & 25857,36 & 297360 & 107747,61 & 1239097 & 1292972 & 14869179 \\
\hline
\end{tabular}

In order to implement that idea, such a mine should have installed a three-chamber pipe feeder; the cost of such device made by SIEMAG is currently about $1 \mathrm{mln}$ zł. Assuming that during a typical working week the cooling installation operates for 120 hours, it follows that a $1 \mathrm{MW}$ installation can generate under optimal conditions the thermal energy worth $1035000 \mathrm{zl}$ during one year. This amount is comparable to the cost of a three-chamber pipe feeder. It follows from this rough assessment that the solution described here could be feasible only in mines having significant cooling power installed, in the order of a couple of MW. It is known from the paper [7] that such a level of cooling potential in Polish mining industry was in 2009 available only in several mines, especially in the mines of Jastrzębska Spółka Węglowa, and eighteen Polish mines had cooling installations of the total power above 1 MW.

\section{CONCLUSION}

A huge amount of heat is transferred from the rock mass surrounding a working into the air stream flowing along the working. Rough estimates show that in a 10-year period after the termination of coal extraction in a given mining district under conditions of natural draught - the induced air flow of the thermal energy of 23820 GJ can be transferred from the rock mass surrounding the workings of the region into the ventilating air stream. The estimated market value of the energy can reach $1095700 \mathrm{zł}(273900 €)$.

The utilization of this energy is not an easy task. The ventilating air is heated underground to the temperature of about $35^{\circ} \mathrm{C}$, but its temperature drops down to $25^{\circ} \mathrm{C}$ when the air reaches the surface level. A promising solution consists in cooling the air underground and then transporting the water heated due to condensation to the surface. The temperature of the hot water leaving the condenser can be as high as $42 \div 43^{\circ} \mathrm{C}$. It should be noted that if several mining regions are present in one mine, then the financial effect of the energy utilization can be worthy of consideration.

An additional benefit arising from the solution involving the hot water transport is the avoidance of problems with heat disposal in surface-located cooling towers during hot summer days. Under such conditions the water circulating in a closed circuit cannot be cooled by the air and returns underground still warm, thus worsening the efficiency of cooling devices.

Our considerations about the feasibility of utilization of the geothermal heat within the mine ventilating air stream carried away to the ambient atmosphere on the surface are restricted to the thermal conditions occurring in Polish coal mines. In these mines, at their deepest levels the virgin rock temperature exceeds now $40{ }^{\circ} \mathrm{C}$, but it is 
generally below $45^{\circ} \mathrm{C}$ [5]. In a copper ore mine Rudna, the virgin rock temperature is $45^{\circ} \mathrm{C}$ and at its planned level $1300 \mathrm{~m}$ deep that temperature is $48^{\circ} \mathrm{C}$. In Czech mines the virgin rock temperature is even higher [6], for example in the ČSA mine it is $44{ }^{\circ} \mathrm{C}$ and more, whereas in the Darkov mine it is $52{ }^{\circ} \mathrm{C}$. In order to secure proper occupational conditions in these mines, cooling installations should be even more powerful than the Polish ones, thus creating the opportunity to remove more heat from the air stream.

It results from the investigations and calculations presented above that the direct utilization of the heat carried away within the mine ventilating air stream is not practical, as the air temperature drops significantly when it reaches surface. It seems that a more feasible solution consists in transporting the hot water from the cooling installations underground to the heating facilities on the surface.

\section{REFERENCES}

[1] BYSTROŃ, H.: Ciąg naturalny i jego charakterystyka w podejściach grawimetrycznym ściśliwym i termodynamicznym do wentylacji podziemnej, Przegląd Górniczy nr 1/2003

[2] HOLEK, S.: Prognozowanie temperatury i wilgotności powietrza w wyrobiskach górniczych z uwzględnieniem przestrzennej i czasowej zmienności czynników. Prace Komisji Naukowych PAN-Oddziat w Katowicach 1979 z.4

[3] HOLEK, S.: Opracowanie potencjału ruchu wilgoci i opartych na nim metod prognozowania mikroklimatu wyrobisk. Prace Naukowe GIG. Seria Dodatkowa. Katowice 1990

[4] KNECHTEL, J.: Badania nad możliwością wykorzystania ciepła geotermalnego wynoszonego z powietrzem kopalnianym na powierzchnię, Zeszyty Naukowe Politechniki Śląskiej, Seria: Górnictwo z.270, Gliwice 2005

[5] KNECHTEL, J.: Przeprowadzenie badań i ocena stanu zagrożenia temperaturowego w oparciu o wyniki prognoz klimatycznych dla rejonu ściany 3 w pokładzie 409 KWK „Wujek” - Ruch „Śląsk”, dokumentacja prac GIG o symbolu 5822279 - 112, maj 2005

[6] KNECHTEL, J.: Wykonanie prognoz klimatycznych i obliczeń zapotrzebowania mocy chłodniczej dla przodków ścianowych i chodnikowych kopalni ČSA (Czechy) według przekazanej dokumentacji, dokumentacja prac GIG o symbolu 58240505 - 112, październik 2005

[7] KNECHTEL, J.: Raport roczny (2009) o stanie podstawowych zagrożeń naturalnych i technicznych w górnictwie węgla kamiennego. Rozdział 6. Zagrożenie klimatyczne. Praca zbiorowa pod kierunkiem prof. dr hab. inż. W. Konopko, GIG - Katowice 2010

[8] KNECHTEL, J.: Wyniki badań dotyczących możliwości wykorzystania ciepła zawartego w powietrzu

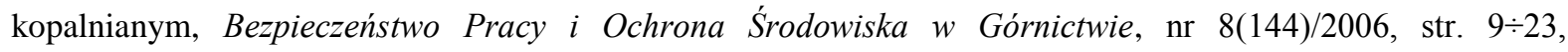
miesięcznik WUG

[9] MUZYCZUK, J.: Samozagrzewanie węgla w procesie jego utleniania strumieniem powietrza w warunkach zbliżonych do adiabatycznych, Prace GIG, komunikat nr 665, Katowice 1974

[10] SZLĄZAK, N., TOR, A., JAKUBÓW, A.: Grupowy system klimatyzacji wyrobisk dołowych w kopalni Zofiówka. Materiały 3 Szkoly Aerologii Górniczej. Artykuł 36, str. 449־462, Zakopane 2004 
SZLĄZAK, N., NAWRAT, S., JAKUBÓW, A.: Pierwsza klimatyzacja centralna w KWK „Pniówek” Jastrzębskiej Spółki Węglowej S.A., Przegląd Górniczy nr 10/2000

WACŁAWIK, J., CYGANKIEWICZ, J., KNECHTEL, J.: Warunki klimatyczne w kopalniach gębokich poradnik, Biblioteka Szkoty Eksploatacji Podziemnej, wyd. PAN - Centrum Podstawowych Problemów Gospodarki Surowcami Mineralnymi i Energią, Kraków 1995

\section{RESUME}

V průběhu větrání dolu okolní skalní masiv odevzdává větrům obrovské množství tepla. $Z$ dosavadních rozvah vyplývá, že v průběhu 10 let po ukončení těžby a ovětrávání větrní oblasti vlivem energie přirozeného větrního tahu, z masivu do ovzduší proudí cca 23820 GJ tepelné energie o ceně cca $109+5700$ zl (273 900 Euro). Ale využití tohoto tepla není tak jednoduché. Jestliže masivem ohřáté ovzduší o teplotě cca $35{ }^{\circ} \mathrm{C}$ odvedeme bezprostředně na povrch, jeho teplota se sniží na cca $25^{\circ} \mathrm{C}$. Zdá se, že vhodnějším řešením je zchlazení tohoto ovzduší v dole a odvedení kondenzačního tepla na povrch vodou chladícího kondenzátoru. Teplota této vody je 42$43{ }^{\circ} \mathrm{C}$. Nutno podotknout, že takovýchto oblastí, o kterých je řeč, může být několik. Potom efekt spojený s odváděním teplé vody na povrch může být značný. Doplňujícím argumentem, hovořícím pro odvádění kondenzačního tepla s teplou vodou na povrch a využití této vody pro komunální účely, je problém odebrání tohoto tepla v komínových chladičích, umístěných na povrchu v době letních veder. Voda cirkulující v uzavřeném okruhu není schopná odevzdat veškeré teplo a vrací se do dolu teplá, v důsledku čehož se zhoršuje efektivita práce chladících zařízení.

V úvahách nad možností využití geotermického tepla vynášeného důlním ovzduším na povrch byl brán zřetel na tepelné podmínky $\mathrm{v}$ teplých kamenouhelných dolech. $\mathrm{V}$ těchto dolech na nejnižších těžebních patrech původní teplota hornin je vyšší než $40^{\circ} \mathrm{C}$, ale obecně nepřesahuje $45^{\circ} \mathrm{C}$. V rudném dole „Rudná“ původní teplota hornin na úrovni $1200 \mathrm{~m}$ dosahuje $45^{\circ} \mathrm{C}$, ale na projektovaném patře $1300 \mathrm{~m}$ dosahuje $48{ }^{\circ} \mathrm{C}$. V českých dolech je původní teplota hornin ještě vyšší. Na závodě ČSA dosahuje $44^{\circ} \mathrm{C}$ a více, na Dole Darkov až $52{ }^{\circ} \mathrm{C}$. Zajištění předepsaných klimatických podmínek v takovýchto dolech vyžaduje instalaci většího chladícího výkonu, a to umožňuje odvádění většího množství tepla.

Z provedených výzkumů vyplývá, že bezprostřední využití tepla, obsaženého v důlním ovzduší, jeho vyvedením na povrch je málo reálné, protože toto ovzduší než dosáhne povrchu se značně ochlazuje. Zdá se, že nejreálnější je odvádění tohoto tepla s teplou vodou vznikající v chladících zařízeních. Vyžaduje to ale investice na pořízení trríkomorových výměníků a dalšího potrubního řadu z dolu na povrch. 